\title{
Identification of Cytophaga psychrophila by PCR Targeted 16S Ribosomal RNA
}

\author{
Takashi Toyama*1, Kumiko Kita-Tsukamoto*2 \\ and Hisatsugu Wakabayashi*1 \\ ${ }^{* 1}$ Department of Fisheries, Faculty of Agriculture, University of Tokyo, \\ Yayoi 1-1-1, Bunkyo-ku, Tokyo 113, Japan \\ *2 Ocean Research Institute, University of Tokyo, \\ Minamidai 1-15-1, Nakano-ku, Tokyo 164, Japan
}

(Received August 31, 1994)

\begin{abstract}
On the basis of the $16 \mathrm{~S}$ rRNA sequence data analysis among the closely related species, the specific primers for Cytophaga psychrophila were constructed. The specificity in amplifying the 16S rRNA of $C$. psychrophila was confirmed by using some selected strains of the related species. In addition, it was revealed that these specific primers distinguished $C$. psychrophila from other principal fish pathogens. The present PCR technique is expected to be a powerful tool for the diagnosis of cold-water disease.
\end{abstract}

Cytophaga psychrophila, the causative agent of cold-water disease, was originally isolated from coho salmon (Oncorhynchus kisutch) in Washington State, USA, in 1948 (Borg 1960). Outside of the North America, Bernardet and Kerouault (1989) reported Flexibacter psychrophilus (syn. C. psychrophila) in diseased rainbow trout (Oncorhynchus mykiss) in France. In Japan, it was isolated from coho salmon, rainbow trout and ayu (Plecoglossus altivelis) (Wakabayashi et al., 1991, 1994). The epizootic has been spreading over Japan, especially among ayu in both farms and rivers.

So far, identification of $C$. psychrophila has been generally conducted on the basis of its phenotypical and/or serological characteristics (Bernardet et al., 1989; Wakabayashi et al., 1994). Recently, many reports have been published on the 16S rRNA sequences of various bacteria and the phylogenetic relationships deduced from analyses of these sequences, and some particular regions of the $16 \mathrm{~S}$ rRNA sequences are known to be species or genus specific (Nishimura et al., 1992). When we use the specific primers for $C$. psychrophila, they enable us a rapid and accurate identification, and provide a useful tool in the epidemilogical investigations.

The aim of the present study is to construct the specific primers for C. psychrophila based on the $16 \mathrm{~S}$ rRNA sequences, and to use them for identification of C. psychrophila by means of PCR.

\section{Materials and Methods}

Construction of the specific primers for C. psychrophila

The species selected for construction of the specific primers are listed in Table 1. These bacteria were selected-according to Nakagawa's $\mathrm{Ph}$. D dissertation (1993), in which, on the basis of 16S rRNA sequences, they were classified from cluster 9 through 12 phylogenetically. The $16 \mathrm{~S}$ rRNA sequence data of all bacteria from cluster 9 through 12 were taken by accessing Nucleotide Sequence Database (GenBank). The selected data were dealt with multiple alignment analysis (CLUSTAL V) (Higgins et al., 1992), and the specific regions for C. psychrophila found out and confirmed the specificity by FASTA (Lipman et al., 1985). The specific primers were synthesized by Sawady Technology Co., Tokyo, Japan according to our profile. These primers, designated PSY1 (5'-CGATCCTACTTGCGTAG-3') and PSY2 (5'-GTTGGCATCAACACACT- $\left.3^{\prime}\right)$, were located at positions corresponding to positions 190 to 206 and 1278 to 1262 , respectively, on the Escherichia coli 16S rRNA numbers. And universal primers conserved in all $16 \mathrm{~S}$ rDNAs, designated 20F (5'-AGAGTTTGATCATGGCTCAG-3') and 1500R ( $5^{\prime}$-GGTTACCTTGTTACGACTT- $3^{\prime}$ ), were also employed (Weisburg et al., 1991). 
Table 1. Species selected for construction of the specific primers for $C$. psychrophila and their sequences corresponding to the positions of the primers

\begin{tabular}{|c|c|c|c|}
\hline \multirow{2}{*}{ Species } & \multirow{2}{*}{ Cluster*1 } & \multicolumn{2}{|c|}{ Sequence } \\
\hline & & $190-206^{* 2}$ & $1278-1262^{* 2}$ \\
\hline C. psychrophila & 12 & $5^{\prime}-\mathrm{G}$ T T G G C A T C A A C A C A C T $-3^{\prime}$ & $5^{\prime}-\mathrm{CG}$ A T C C T A C T T G C G T A G- $3^{\prime}$ \\
\hline F. branchiophilum & 12 & ${ }^{* 4} \mathrm{XX} \cdot \mathrm{C} \cdot \cdot \cdot \mathrm{G} \mathrm{G} \mathrm{T} \mathrm{T} \mathrm{T} \mathrm{T} \mathrm{C} \mathrm{X} \mathrm{C}$ & $\cdot \mathrm{C} \cdot \cdot \cdot \cdot \cdot \cdot \mathrm{CA} \cdot \cdot \cdot \cdot$ \\
\hline C. columnaris & 12 & $\mathrm{~T} \mathrm{~A} \cdot \mathrm{X} \cdot \mathrm{C} \cdot \cdot \mathrm{T} \mathrm{T} \mathrm{T} \mathrm{G} \cdot \mathrm{T} \cdot$ & $\cdot \mathrm{C} \cdot \cdot \cdot \cdot \cdot \cdot \cdot \cdot \cdot \cdot \cdot \cdot \cdot$ \\
\hline F. aquatile & 12 & $\mathrm{AA} \cdot \cdots \cdot \cdot \mathrm{T}$ T T T $\cdot$ T A & $\cdot \mathrm{C} \cdot \cdot \cdot \mathrm{GC} \cdot \cdot \cdot \cdot \mathrm{C} \cdot \cdot$ \\
\hline C. aquatilis & 12 & $\mathrm{CA} \cdot \cdot \cdot \cdot \mathrm{GC} \cdot \mathrm{AC} \cdot \cdot \mathrm{GC}$ & $\cdot \cdot \cdot \cdot \cdot \mathrm{GG} \cdot \mathrm{C} \cdot \mathrm{CC} \cdot \cdot$ \\
\hline C. flevensis & 12 & $\mathrm{TG} \cdot \mathrm{T} \cdot \cdot \cdot \mathrm{GG} \times \mathrm{X} \times \mathrm{AGXG}$ & $\cdot \cdot \cdot \cdot \mathrm{GG} \cdot \mathrm{CA} \cdot \mathrm{CC} \cdot$ \\
\hline Fx. maritimus- $1^{* 3}$ & 10 & T A C T A $\cdot$ C $\cdot$ X G TACT $\cdot T$ & $\mathrm{G} \cdot \mathrm{CAT} \cdot \mathrm{C} \mathrm{T} \mathrm{G} \cdot \mathrm{A} \cdot \mathrm{CA} \mathrm{G}$ \\
\hline Fx. maritimus $-2^{* 3}$ & 10 & $\mathrm{AA} \cdots \cdot \mathrm{GTTTT} \cdot \mathrm{TA}$ & $\cdot \mathrm{C} \cdot \cdot \mathrm{T} \mathrm{C} \mathrm{T} \mathrm{G} \cdots$ C A GA \\
\hline F. indologenes & 9 & $\cdot$ A T AGGGA T $\cdot A \cdot \cdot$ C T G & $\mathrm{T} \cdot \mathrm{CAT} \cdot \mathrm{ACA} \cdot \mathrm{C} \cdot \cdot \mathrm{TGT}$ \\
\hline F. breve & 9 & A & $\cdot \mathbf{C A T} \cdot \boldsymbol{T} \mathbf{T} \cdot \cdot \cdot \mathbf{C A} \cdot$ \\
\hline Fx. aurantiacus & 12 & $\mathrm{AG} \cdot \cdots \cdot \mathrm{CT} \mathrm{T} \mathrm{T} \cdot \mathrm{T} \mathrm{A}$ & $\cdot \mathrm{C} \cdot \cdot \cdot \mathrm{GG} \cdot \mathrm{CA} \cdot \mathrm{CC} \cdot$ \\
\hline C. johnsonae & 12 & $\mathrm{AGX} \cdot \cdots \cdot \mathrm{XCTTT} \cdot \mathrm{T} \mathrm{A}$ & $\cdot \cdot \cdot \cdot \mathrm{GG}^{\cdot} \mathrm{CA} \cdot \mathrm{CC} \cdot$ \\
\hline C. pectinovora & 12 & $\mathrm{XXXC} \cdot \cdot \cdot \mathrm{G} \cdot \cdot \mathrm{T}$ CXG $\cdot$ & $\cdot \cdot \cdot \cdot \mathrm{GG} \cdot \mathrm{C} \cdot \mathrm{CC} \cdot$ \\
\hline C. saccharophila & 12 & A A $\cdots \cdots \cdot$ T T T T G T A & $\cdot \cdot \cdot \cdot \mathrm{GG} \cdot \mathrm{C} \cdot \mathrm{ACC} \cdot$ \\
\hline C. succinicans & 12 & $\mathrm{AA} \cdot \mathrm{X} \cdots \cdots \mathrm{T}$ T T T CAC & $\cdot \cdot \cdot \cdot \cdot \mathrm{GG} \cdot \mathrm{CA} \cdot \mathrm{CC} \cdot$ \\
\hline C. sp. & 12 & $\mathrm{AG} \cdot \cdots \cdot \mathrm{CT}$ T A $\cdot$ T A & $\cdot \cdot \cdot \cdot \mathrm{GG} \cdot \mathrm{X} \cdot \cdot \mathrm{C} \mathrm{C} \cdot$ \\
\hline F. odoratum & 11 & $\mathrm{AA} \cdot \cdots \cdot \mathrm{XGTT} \mathrm{TXTA}$ & $\cdot \cdot \mathrm{A} \mathrm{T} \cdot \mathrm{C} \cdot \mathrm{G} \cdot \cdot \mathrm{C} \cdot \mathrm{G} \cdot$ \\
\hline C. uliginosa & 10 & T A $\cdots \cdot \cdot$ G T A T T TA & $\cdot \mathrm{C} \cdot \cdot \mathrm{TGCG} \cdot \cdot \mathrm{CGCA}$ \\
\hline C. latercula & 10 & $\cdot \mathrm{A} \cdots \cdots \cdot \mathrm{T}$ T T A $\cdot$ T C & $\cdot \mathrm{X} \cdot \cdot \mathrm{T} \cdot \mathrm{A} \cdot \mathrm{XAA} \cdot$ \\
\hline C. marinoflava & 10 & $\cdot \mathrm{A} \cdot \cdots \cdot \mathrm{T}$ C $\cdot$ T T T T A A & $\cdot \mathrm{X} \cdot \cdot \mathrm{TA} \cdot \mathrm{C} \cdot \mathrm{TA} \cdot$ \\
\hline C. lytica & 10 & T A $\cdots \cdots \cdot$ T T T A $\cdot$ A & $\cdot \mathrm{C} \cdot \cdot \mathrm{TA} \cdot \mathrm{C} \cdot \mathrm{T} \mathrm{A} \cdot$ \\
\hline F. meningosepticum & 9 & $\mathrm{AC} \cdot \cdots \cdot \mathrm{G} \mathrm{T} \mathrm{T} \mathrm{A} \cdot \mathrm{T} \mathrm{A}$ & $\mathrm{T} \cdot \mathrm{CA} \mathrm{T} \cdot \mathrm{C} \mathrm{TA} \cdot \mathrm{C} \cdot \mathrm{TAG}$ \\
\hline F. balustinum & 9 & $\mathrm{XXX} \cdot \cdots \cdot \mathrm{GTXXXXA}$ & $\cdot \cdot \mathrm{CAT} \cdot \mathrm{C} \cdot \mathrm{G} \cdot \mathrm{C} \cdot \mathrm{C} \cdot \mathrm{G} \cdot$ \\
\hline$F$. indoltheticum & 9 & A G $\cdots \cdots \cdot$ C T T A T T A & $\cdot \mathrm{CAT} \cdot \mathrm{C} \mathrm{TA} \cdot \mathrm{C} \cdot \mathrm{TAG}$ \\
\hline F. gleum & 9 & $\mathrm{AG} \cdot \cdots \cdot \mathrm{CT} \mathrm{TA} \cdot \mathrm{T} \mathrm{A}$ & $\mathrm{T} \cdot \mathrm{CAT} \cdot \mathrm{ACT} \cdot \mathrm{C} \cdot \mathrm{AG} \mathrm{T}$ \\
\hline
\end{tabular}

*1 Clusters based on 16S rRNA sequences according to Nakagawa's Ph. D. dissertation (1993).

${ }^{* 2}$ Escherichia coli numbering.

${ }^{* 3}$ Two different data can be accessed.

${ }^{* 4} \mathrm{X}$ in the sequence indicates uncertainty in the determination.

${ }^{* 5}$ The species above this line were used for the PCR, and the species below this line not.

\section{Bacterial strains used for the PCR}

The bacterial strains used for the PCR are listed in Table 2. A total of 33 strains was consisted of 23 strains of Flavobacterium-Cytophaga complex from cluster 9 through 12 and 10 strains of fish pathogens belonging to the other genera. The strains are mostly part of our fish pathogen collection (FPC). All strains belonging to the genus Cytophaga or Flavobacterium were grown in tryptone and yeast extract (TYE) broth $(0.4 \%$ tryptone, $0.05 \%$ yeast extract, $0.02 \% \mathrm{CaCl}_{2} \cdot 7 \mathrm{H}_{2} \mathrm{O}, 0.05 \% \mathrm{MgSO}_{4} \cdot 7 \mathrm{H}_{2} \mathrm{O}$, distilled water, $\mathrm{pH}$ 7.2). The strain of Flexibacter maritimus was cultured in Marine TYE broth containing aged sea water instead of distilled water. And the strains belonging to the other genera were grown in brain heart infusion broth. The temperature for cultiva- tion was $25^{\circ} \mathrm{C}$ except for C. psychrophila, which was grown at $18^{\circ} \mathrm{C}$. Cells were harvested at approximately early stationary phase by centrifugation, washed with sterile distilled water, suspended in distilled water to give a cell concentration of $30 \mathrm{mg}$ of wet weight per $\mathrm{ml}$, and stored at $-20^{\circ} \mathrm{C}$.

\section{PCR identification}

For each strain, $40 \mu l$ portions of the above sample was mixed with $10 \mu l$ portions of protenase $\mathrm{K}$ (1 $\mathrm{mg} / \mathrm{ml}$ ) and $50 \mu l$ portions of $2 \times \mathrm{K}$ buffer $(40 \mathrm{mM}$ Tris buffer, $0.2 \%$ nonidet $p-40,0.2 \mathrm{~mm}$ EDTA, $1 \%$ Tween 20, distilled water, $\mathrm{pH} 8.0$ ). The mixture was heat-treated at $60^{\circ} \mathrm{C}$ for $20 \mathrm{~min}$, followed at $100^{\circ} \mathrm{C}$ for $5 \mathrm{~min}$, then cooled rapidly on ice and centrifuged by $8,000 \mathrm{rpm} / \mathrm{min}$ for $5 \mathrm{~min}$ and stored at $-20^{\circ} \mathrm{C}$ 
Table 2. Bacterial strains used for the PCR

\begin{tabular}{|c|c|c|c|}
\hline No.*1 & Species*2 & Strain & Source \\
\hline 1 & C. psychrophila & NCIMB1947 & Coho salmon, Washington, USA \\
\hline 2 & C. psychrophila & FPC840 & Ayu, Tokushima, Japan \\
\hline 3 & C. psychrophila & FPC828 & Coho salmon, Miyagi, Japan \\
\hline 4 & C. psychrophila & FPC813 & Rainbow trout, Tokyo, Japan \\
\hline 5 & C. psychrophila & FPC808 & Rainbow trout, Nagano, Japan \\
\hline 6 & C. psychrophila & FPC924 & Ayu, Wakayama, Japan \\
\hline 7 & C. psychrophila & FPC928 & Ayu, Kyoto, Japan \\
\hline 8 & C. psychrophila & FPC931 & Ayu, Hiroshima, Japan \\
\hline 9 & C. psychrophila & FPC938 & Rainbow trout, Yamagata, Japan \\
\hline 10 & C. psychrophila & SH3-81*3 & Coho salmon, Oregon, USA \\
\hline 11 & C. psychrophila & TG-P01/88*4 & Rainbow trout, France \\
\hline 12 & C. psychrophila & FPC955 & Ayu, Shiga, Japan \\
\hline 13 & C. psychrophila & FPC956 & Ayu, Shiga, Japan \\
\hline 14 & C. psychrophila & FPC957 & Ayu, Shiga, Japan \\
\hline 15 & F. branchiophilum & ATCC35036 & Chinook salmon, Oregon, USA \\
\hline 16 & F. branchiophilum & ATCC35035 & Yamame, Gunma, Japan \\
\hline 17 & C. columnaris & FPC53 & Eel, Shizuoka, Japan \\
\hline 18 & F. aquatile & IAM12216 & \\
\hline 19 & C. aquatilis & IAM12365 & \\
\hline 20 & C. flevensis & IAM12375 & \\
\hline 21 & Fx. maritimus & NCIMB2154 & Red sea bream, Hiroshima, Japan \\
\hline 22 & F. indologenes & FPC954 & Ayu, Shiga, Japan \\
\hline 23 & F. breve & ATCC14234 & \\
\hline 24 & E. coli & $\mathrm{K}-12$ & \\
\hline 25 & Ed. tarda & FPC801 & Eel pond, Shizuoka, Japan \\
\hline 26 & A. hydrophila & FPC868 & Eel, Japan \\
\hline 27 & A. salmonicida & NCIMB2020 & \\
\hline 28 & P. piscicida & FPC851 & Yellowtail, Japan \\
\hline 29 & Y. ruckeri & FPC442 & USA \\
\hline 30 & Ps. anguilliseptica & NCIMB1950 & Eel, Tokushima, Japan \\
\hline 31 & Ps. fluorescens & FPC348 & Japanese Char, Japan \\
\hline 32 & V. anguillarum & FPC346 & Ayu, Shiga, Japan \\
\hline 33 & V. anguillarum & NCIMB6 & \\
\hline
\end{tabular}

${ }^{* 1}$ Numbers used to label lanes in Fig. 1 and Fig. 2.

${ }^{* 2}$ Abbreviations: C., Cytophaga; F., Flavobacterium; Fx., Flexibacter; E., Escherichia; Ed., Edwardsiella; A., Aeromonas; P., Pasteurella; Y., Yersinia; Ps., Pseudomonas; V., Vibrio.

${ }^{* 3}$ Supplied by Dr. R. A. Holt.

${ }^{* 4}$ Supplied by Dr. J. F. Bernardet.

until used for the PCR. Five-microliter portions of these heat-treated cell extracts and 10 pmol primers were used in the PCR. Samples were subjected to 30 cycles of amplification in a DNA thermal cycler (MiniCycler TM; MJ RESEARCH, INC., Massachusetts, USA). A preheating cycle at $94^{\circ} \mathrm{C}$ for 2 min was included. The amplification cycles used for denaturation, primer annealing to the template, and primer extension were as follows: $94^{\circ} \mathrm{C}$ for $2 \mathrm{~min}, 45$ ${ }^{\circ} \mathrm{C}$ for $1.5 \mathrm{~min}$, and $72^{\circ} \mathrm{C}$ for $2 \mathrm{~min}$ for the $20 \mathrm{~F}-1500$ $\mathrm{R}$ and PSY1-PSY2 primer pairs. After 30 cycles of amplification, $10 \mu l$ portions of the PCR products were electrophoresed in a 1.0\% agarose gel, stained with ethidium bromide, and photographed.

\section{Results}

First of all, we confirmed that all preparations contained DNA which could be amplified. The universal 20F-1500R primer pair yielded a fragment of the expected size (Fig. 1). The PSY1-PSY2 primer pair specificially amplified the 16S rDNA of all 14 C. psychrophila strains but none of 19 strains belonging to the other species (Fig. 2). The PSY1- 

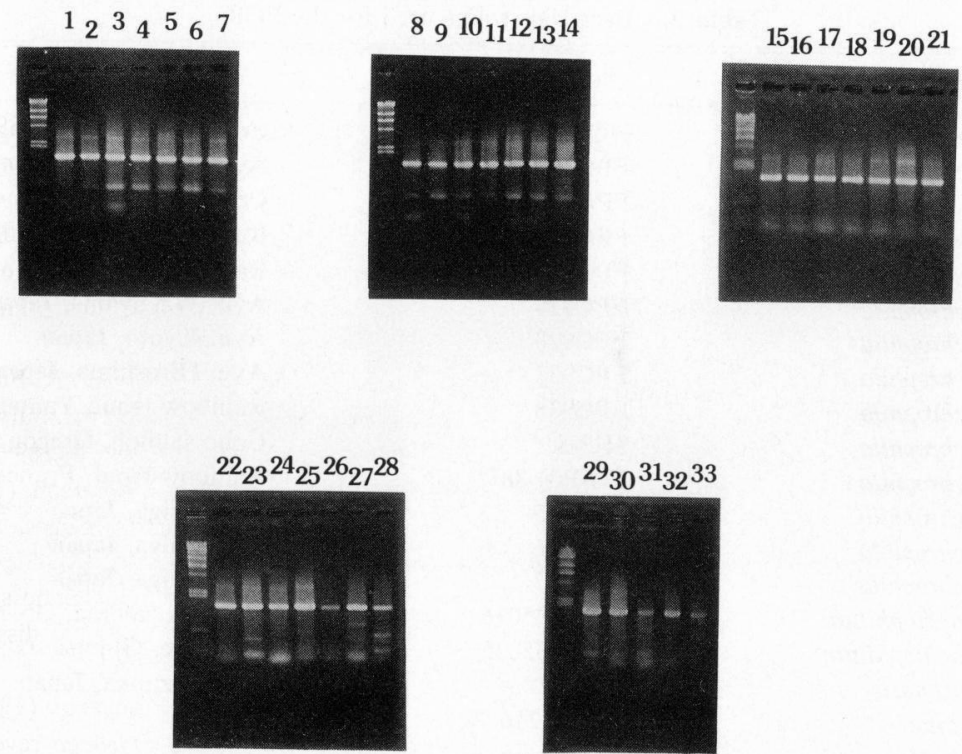

Fig. 1. Results of PCR-assisted amplification by the universal 20F-1500R primer pair complementary to conserved regions in all eubacterial 16S rRNA sequences. See Table 2 for an explanation of the bacterial strain numbers above the lanes. The chromosomal DNA from bacteria was subjected to 30 cycles of amplifications including the primer annealing, at $45^{\circ} \mathrm{C}$. The resulting PCR product was then electrophoresed in an agarose gel, stained with ethidium bromide, and photographed.
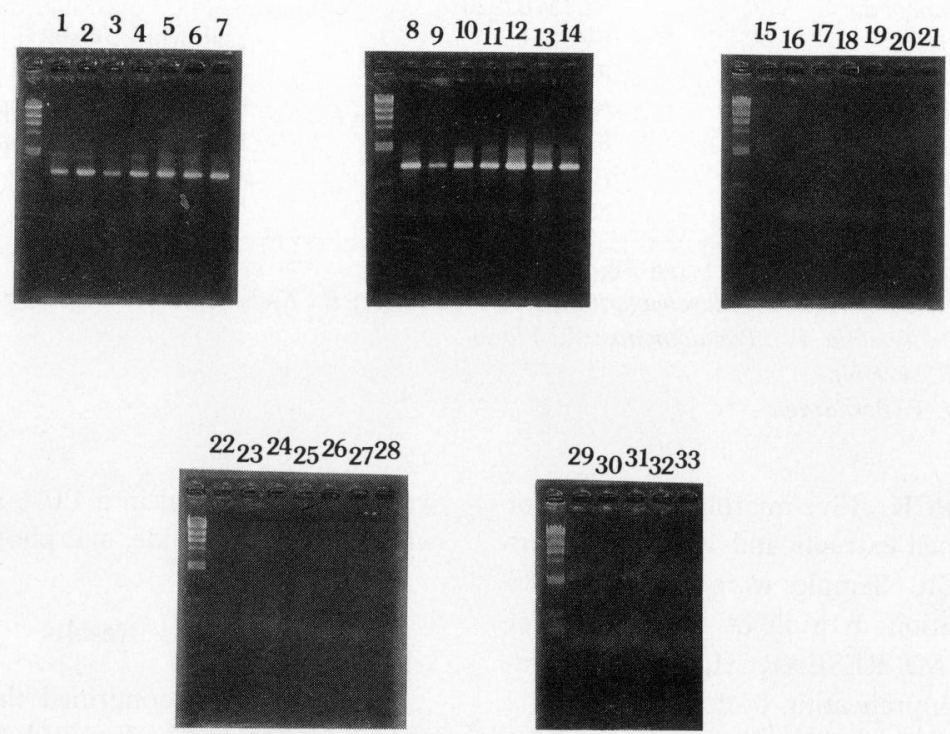

Fig. 2. Results of PCR-assisted amplification by C. psychrophila-specific PSY1-PSY2 primer pair. See Table 2 for an explanation of the bacterial strain numbers above the lanes. The chromosomal DNA from bacteria was subjected to 30 cycles of amplification including the primer annealing, at $45^{\circ} \mathrm{C}$. The resulting PCR product was then electrophoresed in an agarose gel, stained with ethidium bromide, and photographed. 
PSY2 primer pair was assessed for the usefulness for discriminating $C$. psychrophila from other bacteria.

\section{Discussion}

The present results suggested that the PSY1-PSY2 primer pair could differentiate $C$. psychrophila from the other species of Flaobacterium-Cytophaga complex as well as other fish pathogens. The validity of this primer pair for the strains of FlavobacteriumCytophaga complex from cluster 9 through 12 not used for the PCR was assessed by compairing the sequence patterns of the primer positions (Table 1). According to this comparison, the sequence patterns of these regions were significantly different between C. psychrophila and other species belonging to the cluster 9 through 12 . This comparison confirmed that the differences of the sequence patterns considerably had an influence on amplifying the $16 \mathrm{~S}$ rDNA. So it is supposed that the PSY1-PSY2 primer pair will not amplify the 16S rDNA of the other species within these ranges. It is expected that the PSY1-PSY2 primer pair will be a useful tool to identify and detect $C$. psychrophila in the epidemilogical investigations.

\section{Acknowledgments}

We greatly thank Dr. Y. Nakagawa for generously supplying the 16S rRNA sequence data of his $\mathrm{Ph}$. D dissertation. We are also grateful to Dr. K. Ohwada, Dr. K. Kogure, Dr. M. Nishimura, and the members in Marine Microbiology Division, Ocean Research Institute, University of Tokyo, for their advices and encouragements.

\section{References}

Bernardet, J. F. and B. Kerouault (1989): Phenotypic and genomic studies of Cytophaga psychrophila isolated from diseased rainbow trout (Oncorhynchus mykiss) in France. Appl. Environ. Microbiol., 55, 1796-1800.

Borg, A. F. (1960): Studies on myxobacteria associated with diseases in salmonid fishes. Wildl. Dis., 8, 1-85, 2 microcards.

Higgins, D. G., A. J. Bleasby and R. Fuchs (1992): CLUSTAL V; improved software for multiple sequence alignment. Comput. Appl. Biosci., 8, 189-191.

Lipman, D. J. and W. R. Pearson (1985): Rapid and sensitive protein similarity searches. Science, 227, 14351441.

Nakagawa, Y. (1993): Phylogenetic study of Flavobacterium-Cytophaga complex. $\mathrm{Ph}$. D dissertation. The university of Tokyo.

Nakagawa, Y. and K. Yamasato (1993): Phylogenetic diversity of the genus Cytophaga revealed by $16 \mathrm{~S}$ rRNA sequencing and menaquinone analysis. J. Gen. Microbiol., 139, 1155-1161.

Nishimura, M., K. Kita-Tsukamoto, K. Kogure and K. Ohwada (1992): Enumerations of Vibrio cholerae in aquatic environments by MPN-16S rRNA hybridization method. Bull. Jpn. Soc. Microbiol. Ecol., 7, 43-46.

Wakabayashi, H., M. Horiuchi, T. Bunya and G. Hoshiai (1991): Outbreaks of cold-water disease in coho salmon in Japan. Fish Pathol., 26, 211-212.

Wakabayashi, H., T. Toyama and T. Iida(1994): A study on serotyping of Cytophaga psychrophila isolated from fishes in Japan. Fish Pathol., 29, 101-104.

Weisburg, W. G., S. M. Barns, D. A. Pelletier and D. J. Lane (1991): 16S ribosomal DNA amplification for phylogenetic study. J. Bacteriol., 173, 697-703. 